\title{
連鎖探索型遺伝的アルゴリズムの提案と 外ケーブル補強設計問題への応用
}

\author{
鄭 勝仁 1 -中村秀明 $2 \cdot$ 宮本文穂 $3 \cdot$ 藤原 充 4 \\ 1 学生員 修士(工学) 山口大学大学院 理工学研究科博士後期課程（T755-8611 宇部市常盤台2-16-1） \\ 2 正会員 博士(工学) 山口大学助教授 工学部知能情報システム工学科(テ755-8611 宇部市常盤台2-16-1) \\ 3 正会員 工博 山口大学教授 工学部知能情報システム工学科( テ755-8611 宇部市常盤台2-16-1) \\ 4 修士(工学) 日立システムエンジニアリング（テ143-8545 東京都大田区大森北3-2-16）
}

\begin{abstract}
本研究では, 離散値空間に対する解探索手法として近年注目されている遺伝的アルゴリズム（GA）に 着目し, 解空間から複数の近似最適解を探索することを目的としたGAベースの解探索手法である連鎖探 索型GA（RS-GA）を提案している. RS-GAは，所謂，単純GAを基本として解探索を連続的に行い得るア ルゴリズムとして改良している.このことから, 例えば構造最適化問題にRS-GAを応用した場合, 設計空 間から高適応度を有する設計可能解を複数探索することが期待される. 以下では，2次元および3次元の 多峰性関数を例に用いてRS-GAの解探索特性を検証し, その後, 工学問題への応用として合成鈑析の外 ケーブル補強設計問題を例に, RS-GAの有用性を複数の近似最適解の探索結果をもとに考察している.
\end{abstract}

Key Words : genetic algorithm, relay search method, effective solution, multi-optimum design, design for strengthening, prestressing with external tendons

\section{1. まえがき}

近年, 工学分野において組合せ最適化問題や離散 システムの最適化問題などに対する近似解法の一つ として，遺伝的アルゴリズム（Genetic Algorithm, GA） 1)，2) が注目されている.GA の特徴を従来 からある極值探査法と簡単に比較すると，極值探査 法が勾配情報（微分係数）を用いた一点探索手法で あるのに対し，GAは勾配情報を必要とせず，適応 度関数（目的関数を無制約変換した関数）に依存す る複数点探索情報を使った全探索点の協調的作業の 結果として最適解を探索する.このことから GA は， 特に微分不可能あるいは陰な関数表現からなる目的 関数の最適化問題に対する, 新たな数値計算アルゴ リズムとして期待がもたれている ${ }^{3)}$.

一般に，実践的な最適化問題の多くは，厳密な大 局的最適解に対する求解要求より, 実行可能性の高 い複数の最適解に対する求解要求の方が，より実用 的な視点からは望まれると言える．例えば，実践的 な多目的最適化問題の場合, 目的関数の重み付けで 設計者の意図を統合する考え方には限界があるため, 㛜密な求解結果が実践的には意味を持たないことも 起こり得る.このように, 繁雑な検討作業の結果, 厳密な求解に至ったとしても, その一方で, 算出解 が設計者の意図に反すると言った危険性も同時に有 していると思われる。
このような問題に対し，GA あるいは GA 同様に 生体の遺伝的および免疫的機能を数理モデル化した IA（Immune Algorithm）をその解法として適用する 研究が試みられている4)，5）。その際，例えば，局 所解が多数存在する多峰性問題に GA を適用する場 合，標準的な遺伝的操作のみの GA（単純 GA）で は，個体の未成熟期で見られる収束現象に対する懸 念や上述した多目的最適化問題がもつ限界性などに 直面することに，どのように対処するかが課題で あった。この課題に対しこれらの問題点を改善し 効果的な解探索を実現するため, 幾つかの GA の拡 張手法が提案されている ${ }^{6)}$ 。これまで提案されて いる各手法を着想上の特徽で分類すると, (1)「個体 の多様性を大域的に維持する考え方」，(2)「アルゴ リズムの実行時に得られる高適応度解情報を活用す る考え方」，そして(3)「GA のような大域探索向き アルゴリズムと局所探索向きアルゴリズムとによる 協調的探索（ハイブリッド手法）の考え方」のおお よそ3つに大別できる.この(1)〜(3)に分類できる各 手法は，それぞれの特長を活かした解探索を行うこ とで目的の解探索性能を確保することが理解されて いる. また一方の IA は, 解の探索過程で獲得した 有効抗体の記憶細胞と抑制細胞への分化機構および 抑制細胞による抗体産生の抑制機構を数理モデル化 することで, 多峰性問題の最適化を可能にする点が 特徴と言える ${ }^{7)}$. 
このように, 多峰性問題に対応した GA ベースの 解探索アルゴリズムが種々研究されている. しかし その一方で, 手法利用者の立場に立脚すると拡張 GA やIA の総体的な理解は容易であるとは言えず, 拡張 GA あるいは IA の本質である生体の複雑なメ カニズムに対する理解がある程度求められる.この ことから, 手法の実践問題への利用性および汎用性 の視点からは問題も多いと言える.

そこで本研究では，上記(2)の考え方を参考に単純 GA をべースにしたアルゴリズムを比較的簡単に多 峰性問題に適用するため, 単純 GA を複数回繰り返 すことを基本にした連鎖探索型遺伝的アルゴリズム

(GA with Relay Search Method, RS-GA) を提案し ている. 本手法の特徵は, 単純 GA を連続的に繰り 返して順次得られる高適応度解情報を利用し, 大域 的に複数の解（候補）を探索する.このことにより， 比較的アルゴリズムが容易と考えられる単純 GA を わずかに改良することで, 単純 GA で彩念される初 期収束に対する馝念が緩和され，さらに大域的な解 探索が可能になる.

本論文では, まず第 2 章でGAについて, 主に単 純GAの考え方を中心に概説している. 第 3 章では, 本研究で提案するRS-GAについて解説し, さらに2 次元および3次元の多峰性関数を例に用いたRS-GA の数值シミュレーションから, RS-GAの解探索特性 を考察している. 第 4 章では, RS-GAのケーススタ ディとして外ケーブルプレストレス補強設計問題を 例に，その有用性を検討している.

\section{2. 遺伝的アルゴリズム}

\section{(1) 概 説}

GA の研究は, 生物物理学の研究分野で生命現象 を理論解明する際のモデル構築を目的にスタートし た. そのため, 計算機科学領域で 1950 年当時に盛 んであった人工進化システムの研究成果と, 生物科 学領域における集団遺伝学の研究成果を互いに融合 するように研究が展開されてきた。このことから， 研究当初は今日的に云われている“人工生命 (Artificial-Life) ”研究のうち, 理学的研究 (科学 指向研究）が中心課題であり, その結果, 個別の生 命現象を説明するための緻密で複雑なモデル化が発 達している. その一方で, 当時は工学的な視点から の研究（工学指向研究）が欠落していたが, その後, 1970 年代中頃に計算機科学者の J.H.Holland が, 生 物の遺伝機構を模倣した人工進化システムを体系的 に整備した研究成果を発表し, それを契機として
様々な工学的応用研究が試みられ始めている. その 結果, その有用性が工学領域全般で次第に認識され 始めるに至っている8)，9).

本研究で注目する GA は, メンデルの「遺伝の法 則」により実証されたダーウィンの「進化理論」か ら, 最新理論の「新総合進化論」10) までを背景に して考案された数値計算アルゴリズムである. その アルゴリズムは，基本的に染色体（個体）集団が生 存環境へ高度に『適応』する機能を前提に, 『選 択・淘汰』『交叉』『突然変異』を絽り返す進化プ ロセスの数理モデルに基づく. さらに，その進化プ ロセスでは個体集団の多様性を巧みに機能させるこ とで, 個体集団は協調的に世代進化を繰り返し，そ の結果, 優位な世代情報を次世代集団に伝達（遺 伝）することができる.

このような GA を構造システムの最適化問題に応 用した場合, 繰り返し世代更新が起こる個体集団 (設計解候補集合) は，世代情報（適応度に基づく 当該解の良否情報）を手掛かりにして最適解の探索 に向かうことが伺われる。また，一点探索法（最急 傾斜法, 確率的山登り法などの極值探索法) が局所 解に陥り易いのに比べ, GA は局所解に捕らわれに くい.これは, 多点探索法を採る GA では, 一度局 所解に陥ったとしても, 個体集団が協調的かつ大域 的に解探索を実施することにより，確率的にそこか ら脱出しやすいと言った $\mathrm{GA}$ 特有の性質による.こ のように, 線形·非線形関数, 不連続関数および離 散システムに対し有効に機能し, さらに, 汎用性に 富んだアルゴリズムである GA は, 複雑な実践的最 適化問題に対する有用性が期待される.

土木構造システムの最適化問題における GA の応 用研究は, 計画 ${ }^{11)}$, 設計 ${ }^{12)}$, 施工管理 ${ }^{13)}$ におけ る諸問題および支援システムの構筑 ${ }^{14)}$ などで既に 数多く試みられており， GA の可能性に関する議論 がますます深められている.

\section{(2) 単純 GA の処理手順}

本項では，まず GA の基本的な処理手順を確認す るため, 図-1 に示す単純 GA のフローチャートを 用いて, 以下のように端的に解説する.

(1) : 単純 GA パラメータの設定

最終世代, 集団サイズ, 交叉確率, 突然変異確 率といった GA 戦略上のパラメータを設定する.

(2) : 初期集団の産生

ランダムに個体を産生し初期集団とする.

(3) : 適応度の評価

集団の各個体適応度を評価する. GA 戦略に 『エリート保存戦略』を導入する場合, 集団内 


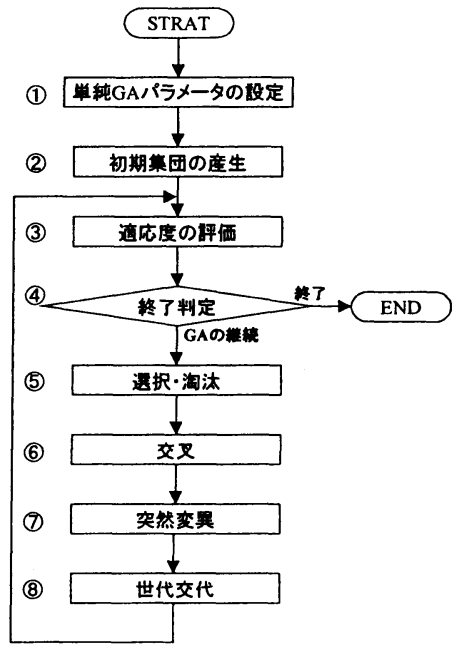

図-1 単純 GA のフローチャート

で最大適応度の個体をその世代の “エリート個 体”として, 次世代集団に優先的に組み込む.

(4): 終了判定

終了条件（一般に, 総世代や解の収束率などを 利用）に到達した時，計算を終了する.

(5)：選択・淘汰

個体選択の方法として種々の方法が提案されて いる2）が, 基本は適応度の程度に応じた個体選 択による，選択された個体は親個体として交叉 プールに入れる.これを交叉プール中の個体数 が選択個体数に達するまで繰り返す.

(6) : 交叉

選択方法同様, 種々の交叉方法が提案されてい $る^{2)}$. 基本は，交叉確率に応じて交叉プールよ り親個体を 2 個体選出し，それらを交叉させて 次世代の子個体を産生する.

(7) : 突然変異

(5)，(6)で生成された子個体集団において，任意 個体中のある遺伝子座の遺伝子を, 突然変異確 率に応じて対立遺伝子に置き換える．例えば， 遺伝子に 2 進数を用いた場合では，“0”遺伝子 に対する対立遺伝子は“1”となる。

(8)：世代交代

(7)までで新たに産生された集団（次世代集団） を親集団（旧世代集団）と入れ替える. その後, エリート個体を次世代集団に含め(3)一戻る.

単純 GA は, 多点探索法により解探索を行うため, 局所解に捕らわれにくい。しかし，非線形性の強い 探索域に単純 GA を適用した場合，解探索が不十分 な時点で多様性が失われ，解の探索効率が低下し， 解探索の早期で陥った局所解から抜け出せないまま
解の収束に至る（所謂「初期収束」）現象が獎念さ れる.このような個体の多様性喪失問題を改善する ために, Goldberg はシェアリング法 ${ }^{1)}$ を提案して いる，本研究で提案する RS-GA はその方法と異な り, 基本的に単純 GA を連続実行し, さらに順次得 られる収束解情報を活用することで多様性の維持を はかっている，それについては次章で詳しく述べる.

\section{3. 連鎖探索型遺伝的アルゴリズム}

\section{(1) 概 要}

本研究では, 複数の最適解の探索が可能な手法 として, 単純 GA ベースの連鎖探索型 GA（RSGA）を提案している. RS-GA を簡単に説明すると, 「一回の極值解収束を処理単位とする単純 GA を, 複数回にわたり連続実行させることで, 複数の最 適解を挆索する解探索アルゴリズム」と言える。 RS-GA の特徴は, 単純 GA を繰り返すと言った理 解容易なアルゴリズムの採用および複数解を算出 するために考案した個体の分散化手法にある. 以 下では RS-GA の特徴と処理手順について詳述する.

\section{（2）特 徵}

a) “Family”と “Familyエリート”

RS-GA は, 極值解への収束事象を処理単位とす る単純 GA を連続的に実行させて, 複数の最適解を 探索する解探索アルゴリズムである.このことから， RS-GA では，アルゴリズムを改良することで，一 度発見された最適解がその後の探索過程において, 幾度となく再探索されてしまうことを防いでいる。

そこで, 処理単位の単純 GA 処理のことを RSGAにおける“Family”と称し，さらに， “Family” 毎で探索される最適解を“Family エリー ト”として探索アルゴリズムに活用することで, 一 度探索された最適解およびその類似解を, RS-GA が解空間を探索し続ける間，再度探索しないように エ夫をしている.

図-2 は, 一変数問題（4つの極大值探索問題）を 例に, RS-GA による複数解の探索概念を図示して いる．同図を用いて RS-GA の概念を説明する．ま ず, “Family-1（RS-GA において第 1 回目の単純 $\mathrm{GA}$ 処理) ”により最適解である “Family エリート 1 $\left(V_{o p l}\right)$ ”が探索される.この解は, RS-GA の手 法論上, 寸なわち第 1 回目の単純 $\mathrm{GA}$ 処理と言うこ とで，もっとも適応度の高い解が発見される確率が 高い. 続いて，“Family-2（RS-GA において第 2 回 目の単純 GA 処理 ; 以下同様) ”により $V_{o p l}$ を除い た最適解 “Family エリート 2 $\left(V_{o p 2}\right)$ ”が探索され 


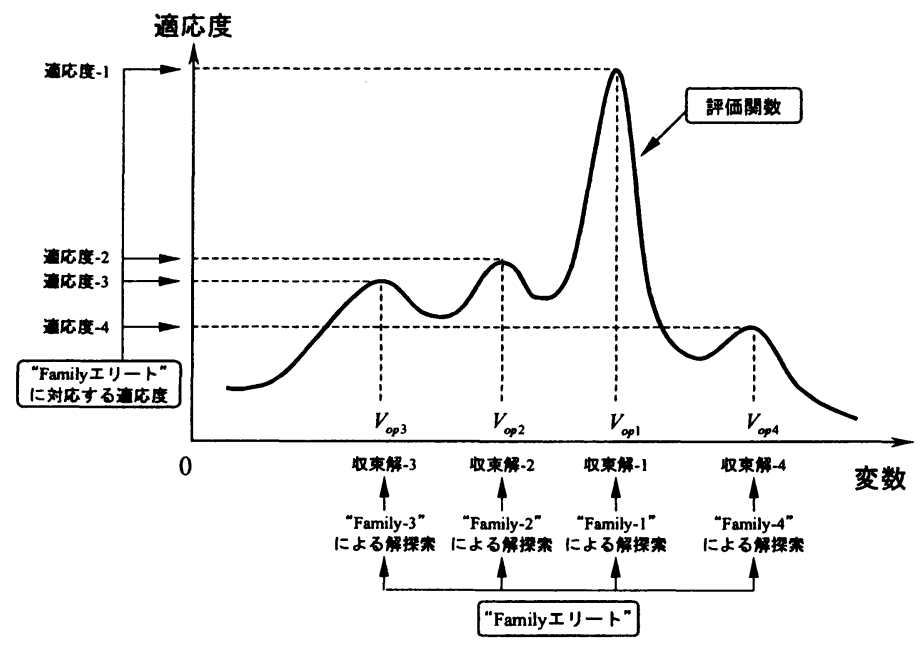

図-2 RS-GA における複数解の探索概念

る. その際, 再度 $V_{o p 1}$ およびその類似解を探索しな いように, “Family-2” の処理プロセスを通じて $V_{o p 1}$ と同じもしくは類似した解に対して, 適応度を 抑制する処理を施す.これにより抑制対象の解（個 体）に対して淘汰圧力が一層強まることになる.同 様に，“Family-3”では，基本的に以上の操作を繰 り返すが，適応度の抑制対象に対して淘汰圧力を強 める操作に， $V_{o p 1}$ だけでなく $V_{o p 2}$ を活用する. その 後, “Family-4” でも同様な操作を繰り返す.

同図の例を踏まえて，この解探索プロセスを一般 化すると，「“Family- $(i)(i \geqq 2)$ ”での単純 GA 処 理では, “Family- $(i-1) ”$ 以前に探索済みの最適解 集合を, 全て解探索の淘汰圧力を強める操作に活用 し, 重複した最適解およびその類似解の探索を抑制 する一方，さらなる最適解を探索する」となる.

さらに, このことにより, RS-GA の終了期まで 個体の多様性を, “Family”と “Family エリート” が維持し続ける機能を生みだしていると評価できる. その結果, GA で一般的に㦟念される局所解収束が 回避され, 大域的探索をした結果と等価な探索効果 が RS-GAにより可能となる.

\section{b) “Family エリート”と適応度の抑制手法}

本項では，上述した “Familyエリート”を活用し た個体の抑制法について説明する.

いま，説明を簡略化するために，抑制対象の “Familyエリート”が既に 1 個体存在した “Family2”における抑制操作を例に用いる。この場合,

“Family エリート”に依存した個体の抑制は,

“Family エリート $\left(V_{\text {opl }}\right) ”$ と “Family-2”の各世代集 団との類似程度に基づく，一般に，2 個体間の類似 度の測定には，ハミング距離や情報エントロピーな

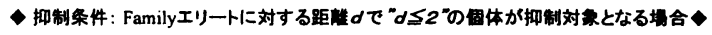

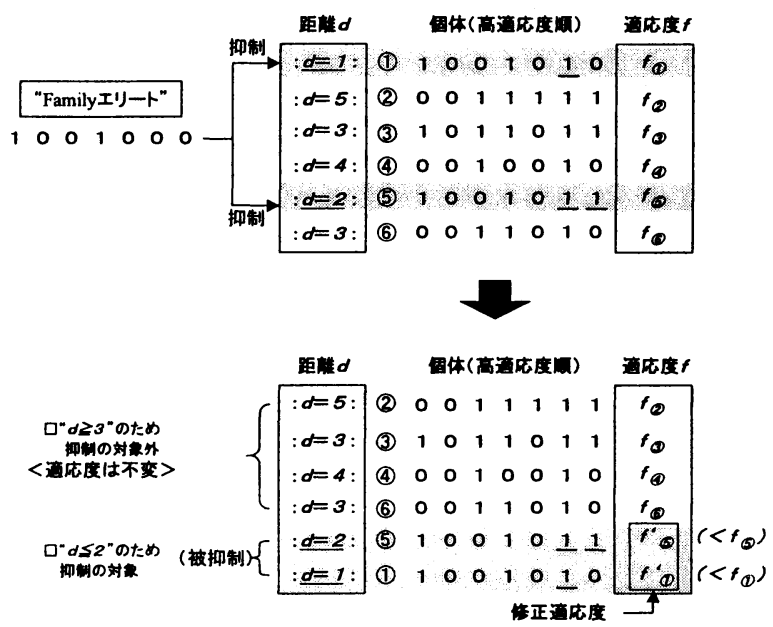

図-3“Familyエリート”による個体抑制の考え方 (集団サイズが 6 個体の場合を例に)

どの指標が用いられるが，RS-GA では前者を用い ている。 ハミング距離（以下「距離」） $d$ は，2 個 体間が $100 \%$ 一致していると “ $d=0 ” ， 100 \%$ 一致し ていなければ “ $d=「$ 個体ストリング長」（例えば 2 進数遺伝子で個体ストリング長が 10-bit 長の場合, $d=10$ となる）」といった值を示す. 図-3に示した 例は，集団サイズが 6 個体，個体ストリング長が 7bit からなる個体集団の場合に，適応度の抑制条件 として距離 $d$ が 2 以下の時に適応度を抑制させるこ とを示している.

このように，適応度に抑制が加えられた「修正適 応度」を有することになる個体は，適応度抑制の範 


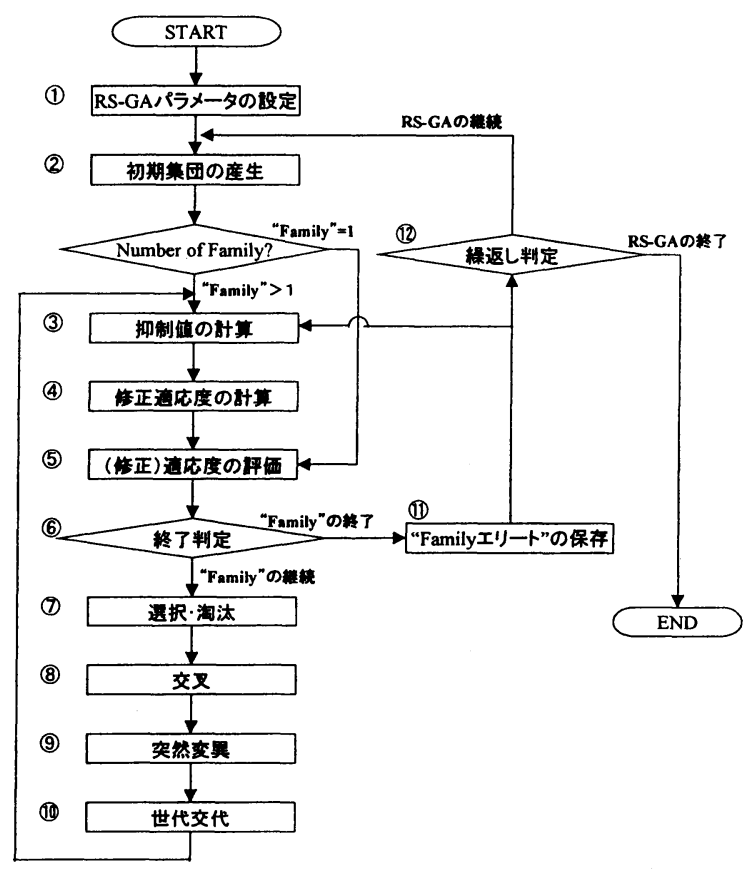

図-4 連鎖探索型 GA(RS-GA)のフローチャート

囲外にある個体の適応度と順位が入れ替わる.この ような操作が “Family-2”の各世代で逐次実行され るので, 適応度を修正された個体は一層の淘汰圧力 を受け, その結果, 次期の “Familyエリート” 個体 $\left(V_{o p i}\right)$ として探索されなくなる.さらに，“Family” が更新され続けると“Family エリート”が順次算出 されるのと同時に，それらは各 “Family”における 抑制個体として記憶され，探索域における個体の分 散化（探索解の多様化傾向）に大きく貢献する.

実際，個体間の類似度に基づく適応度抑制の方法 にはいくつかの方法が考えられるが, ここでは式 (1)および式(2)のように定義する修正適応度および 適応度抑制関数により, 適用度抑制を行う。

$$
\begin{gathered}
f^{\prime}=f \times g_{p}(d) \\
g_{p}(d)=\left(\frac{d(p, q)}{d_{0}}\right)^{\alpha}
\end{gathered}
$$

ここで, $f$ : 適応度, $f^{\prime}$ : 修正適応度, $g_{p}(d)$ : 個 体 $p$ の適応度抑制関数, $d(p, q)$ : 個体 $p$ と $q$ 間の八 ミング距離, $d_{0}$ : 距離に基づく適応度抑制のしきい 值, $\alpha$ : 適応度抑制パワー.

\section{(3) RS-GA の処理手順}

前節では，RS-GA における適用度抑制方法を解 説した。本節ではその方法を用いて単純 GA を改良 した RS-GA の処理手順について, 図-4 に示すフ ローチャートを用いて説明する.

(1) : RS-GA パラメータの設定

単位 Family の世代数, 集団サイズ, 交叉確率, 突然変異確率および繰返し回数 (総 Family 数) といった RS-GA 戦略のパラメータを決定する.

(2) : 初期集団の産生

ランダムに個体を産生し初期集団を生成する.

(3) : 抑制値の計算

これまでに確定した “Family エリート”と当該 Family 中の各個体とのハミング距離を測定し, それに基づき各個体の抑制値を算出する.

(4) : 修正適応度の計算

(3)で算出した各個体の抑制值を, 正規の適応度 に乗じた修正適応度を求める。

(5)：（修正）適応度の評価

(4)で求めた修正適応度を再評価する。任意 Family においてエリート保存戦略を導入するな ら, 集団内で最大の修正適応度の個体をエリー 卜個体として，優先的に扱う。

(6): 終了判定

終了世代に達したならば計算を終了し, (11)八進 む.そうでないなら(7)へ進む.

(7)：選択・淘汰（単純 GA に準ずる）

(8): 交叉 (単純 GAに準ずる)

(9) : 突然変異（単純 GAに準ずる）

(10)：世代交代

(9)までで新たに産生された集団（次世代集団） を前の集団（旧世代集団）と入れ替える。工 リート個体を集団に含め世代を更新し(3へ戻る.

(11) : “Familyエリート”の保存

各任意 “Family” で得られた最終的なエリート をこれ以降の探索解の適応度抑制に利用するた め “Family エリート”として記憶する.

(12) : 繰り返し条件判定

あらかじめ決めた繰り返し回数に到達したら RS-GA を終了する.そうでないなら(2)へ進む.

\section{（4） RS-GA の解探索特性}

本節では，前節で計算プロセスを説明した RSGA の解探索性能を検証する. また, RS-GA の特徵 の理解を容易にするため, その比較対象として単純 GAの結果を併記している.

\section{a) 例題の設定}

例題には，以下に示す最適解 (ピーク解) が既知 である多峰性関数 F1，F2 および F3 を用いた。 
表-1 関数 FI の最適解 (ピーク解)

\begin{tabular}{|c|c|}
\hline$x$ & $F 1(x):$ 適応度 \\
\hline 0.10 & 1.0 \\
\hline 0.30 & 1.0 \\
\hline 0.50 & 1.0 \\
\hline 0.70 & 1.0 \\
\hline 0.90 & 1.0 \\
\hline
\end{tabular}

表-2 関数 F2 の最適解（ピーク解）

\begin{tabular}{|c|c|}
\hline$x$ & $F 2(x):$ 適応度 \\
\hline 0.10 & 1.0 \\
\hline 0.30 & 0.9 \\
\hline 0.50 & 0.7 \\
\hline 0.70 & 0.5 \\
\hline 0.90 & 0.3 \\
\hline
\end{tabular}

表-3 関数 $F 3$ の最適解（ピーク解）

\begin{tabular}{|c|c|c|}
\hline$x$ & $y$ & $F 3(x, y)::$ 適応度 \\
\hline 0.100 & 0.100 & 2.000 \\
\hline 0.100 & 0.300 & 2.000 \\
\hline 0.100 & 0.500 & 2.000 \\
\hline 0.300 & 0.100 & 2.000 \\
\hline 0.300 & 0.300 & 2.000 \\
\hline 0.300 & 0.500 & 2.000 \\
\hline 0.500 & 0.100 & 2.000 \\
\hline 0.500 & 0.300 & 2.000 \\
\hline 0.500 & 0.500 & 2.000 \\
\hline
\end{tabular}

\section{F1 : Five-peak 関数}

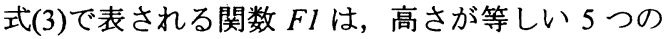
ピークを持つ等周期関数である. Fl の最適解とそ の適応度を表-1 に示す（例えば図-5 (1) 参照）。

$$
F 1(x)=\sin ^{6}(5 \pi x) \quad\{x \mid 0 \leq x \leq 1.0\}
$$

\section{F2 : Decreasing Five-peak 関数}

式(4)で表される関数 $F 2$ は, 高さが異なる $5 つ の$ ピークを持つ等周期関数である. F2 の最適解とそ の適応度を表-2に示す（例えば図-5(2) 参照）。

$$
\begin{gathered}
F 2(x)=\exp \left[-2 \log (2)\{(x-0.1) / 0.8\}^{2}\right] \sin ^{6}(5 \pi x) \\
\{x \mid 0 \leq x \leq 1.0\}
\end{gathered}
$$

\section{F3 : Nine-peak 関数 (3 次元)}

式(5)で表される関数 F3 は，Fl 関数を二つ組合 せた 3 次元合成関数である. $F 3$ の最適解とその適 応度を表-3に示す（図-9参照）。

$$
\begin{aligned}
& F 3(x, y)=\sin ^{6}(5 \pi x)+\sin ^{6}(5 \pi y) \\
& \{x|0 \leq x \leq 1.0, y| 0 \leq y \leq 1.0\}
\end{aligned}
$$

\section{b) GA 戦略パラメータの設定}

表-4 に, 本シミュレーション上の GA 戦略パラ メータの設定状況を示す，その詳述は省略するが,

\begin{tabular}{|c|c|c|}
\hline & 单絰GA & $\overline{\mathrm{RS}-\mathrm{GA}}$ \\
\hline 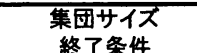 & 30個体 & $\begin{array}{c}30 \text { 個体/Family } \\
\text { (F) }\end{array}$ \\
\hline 遭伝子型 & & 数 $\left(" 0^{n} \mathrm{or}^{n} 1 "\right)$ \\
\hline 個体ストリングス長 & & 10-bit \\
\hline 交叉確率 & & $20 \%$ \\
\hline 突然変異率 & & $1 \%$ \\
\hline 選択操作 & & 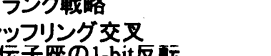 \\
\hline & & \\
\hline
\end{tabular}
同表に示すように, 本シミュレーションでは, 単純 GA およびRS-GA の解探索特性を比較するため, 可

\begin{tabular}{|c|c|}
\hline & RS-GA \\
\hline $\begin{array}{l}\text { 集団サイス } \\
\text { 終了条件 }\end{array}$ & $\begin{array}{c}30 \text { or } 100 \text { 個体/Family } \\
18 \text { Family(30世代/Family) }\end{array}$ \\
\hline 遺伝子型 & 2進数 ("0"or"1") \\
\hline 個体ストリングス長 & 18-bit \\
\hline 交叉確亳 & $20 \%$ \\
\hline 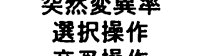 & $\begin{array}{l}\text { ランク } \\
\text { ラン戦略 }\end{array}$ \\
\hline $\begin{array}{l}\text { 交叉操作 } \\
\text { 然变異操作 }\end{array}$ & $\begin{array}{l}\text { シャ゙ッフリング交叉 } \\
\text { 任意螣伝子座のl-bitt反転 }\end{array}$ \\
\hline
\end{tabular}

表-4 本シミュレーションにおける GA 戦略パラメータ

(1) 関数 $F 1, F 2$

(2) 関数 $F 3$

能な限り基本的な $\mathrm{GA}$ 戦略パラメータの条件を統一 するように配慮した。終了条件は, 単純 GA では 200 世代で終了とし, RS-GA では単位 Family 20 世代で終了とした計 10-Family の探索を行った. な お, 関数 F3 に対するシミュレーションは, RS-GA のみで行った．また，本節で示したシミュレーショ ン結果は, 初期集団のランダム産生からなる解探索 シミュレーションを数回行って得た結果の内で, 代 表的なものを示している.

\section{c) 結果と考察}

\section{単純 GAについて}

まず，単純 GA の結果について考察する．表 -5 に得られた収束解を示す。 また, 図-5 は, 探索終 了時の結果である. 図中の○マークは, 関数 Fl, F2 のそれぞれで最終世代までに進化した個体をプ ロットしたものである.

同表および同図から関数 $F 1$ に関しては，5つの 最適解の内, 大部分の個体がある解 $(x=0.3)$ に収 束していることが分かる（図-5(1) 参照）. 一方, 関数 $F 2$ に関しては, 最大ピーク解 $(\mathrm{x}=0.1)$ に収束 していることが分かる（図-5(2) 参照）。単純 GA では, 適応度の高い個体ほど次世代集団に自身の遺 伝子情報を反映させられる確率が高い。このため, 関数 Fl は 5 つの最適解が全て同一の適応度 $(F I=1.0)$ を示すことから，最適解を探索する際に どの最適解を探索するかは, 単純 GA が持つ蓋然性 に依存すると言える. 一方, 関数 F2 の場合, 先の 蓋然性よりも適応度情報が優先するため, 個体が局 所解にトラップされない限り, ほぼ高い確率で最大 ピーク解 $(\mathrm{x}=0.1)$ に収束すると考えられる. なお, 複数回行った本シミュレーションでは，ほぼ全試行 回数で最大ピーク解に収束する結果を得ている. 


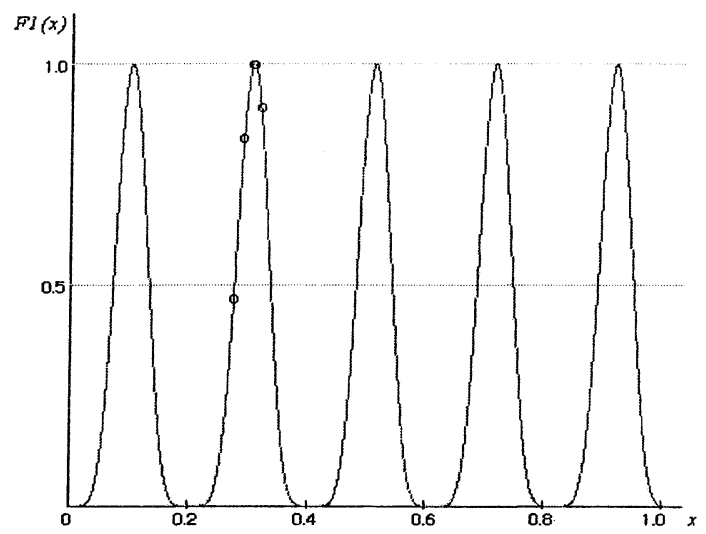

（1）関数FIに適用した場合

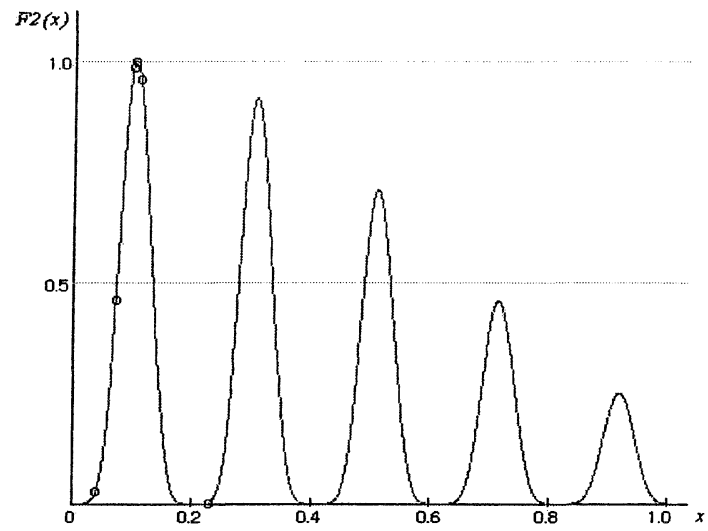

（2）関数 $F 2$ に適用した場合

図-5 単純 GA の探索終了結果（図中○は個体を示す）

表-5 単純 GAによる収束解

\begin{tabular}{|c|c|} 
(a) & 関数 $F 1$ の解 \\
\hline$x$ & $F 1(x)$ \\
\hline 0.3001 & 0.999998 \\
\hline
\end{tabular}

\begin{tabular}{|c|c|} 
(b) & 関数 $F 2$ の解 \\
\hline$x$ & $F 2(x)$ \\
\hline 0.0997 & 0.999999 \\
\hline
\end{tabular}

\section{RS-GA について}

以上のように，単純 $\mathrm{GA}$ は関数 F1 および F2 に対 して近似最適解の探索を行うが，一度収束解に到達 してしまうと, 他の最適解 (ピーク解) の探索には 向かわないことを確認した。

そこで，RS-GA についても同じ関数を用いたシ ミュレーションを行った。図-6に RS-GA による関 数 $F 1, F 2$ についての結果を示す. なお, 図中の マークは，各 Familyで選択された Familyエリート, ○マークは最終 Family の個体を表す。また，表-6 に各 Familyで得られた Familyエリートを示す.

図-6(1) および表-6(1)より，RS-GA が関数 F1に 対して 5 つの近似最適解を探索していることが分か

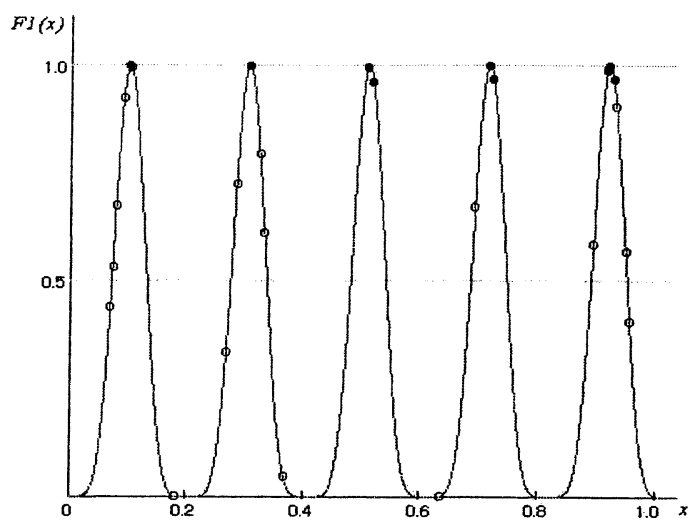

（1）関数 F1に適用した場合

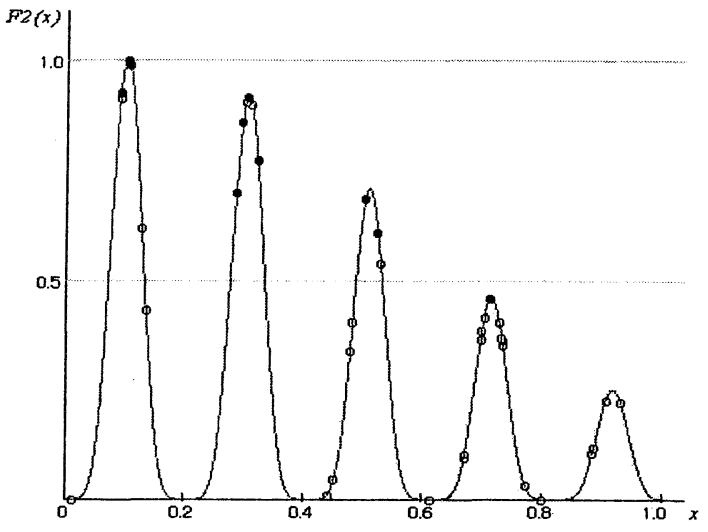

(2) 関数 $F 2$ に適用した場合

図-6 RS-GA の探索終了結果

(図中：“Familyエリート”，○：最終 Family 個体)

表-6 RS-GAによる収束解

\begin{tabular}{|c|c|c|}
\hline (1 & \multicolumn{2}{|c|}{ 関数 $F 1$ の解 } \\
\hline Family & $x$ & $F f(x)$ \\
\hline 1 & 0.0997 & 099999 \\
\hline 2 & 0.9003 & 10000 \\
\hline 3 & 0.3001 & 1,0000 \\
\hline 4 & 0.6999 & 0.9998 \\
\hline 5 & 0.9071 & 0.9675 \\
\hline 6 & 0.1026 & 0.9951 \\
\hline 7 & 0.4976 & 05946 \\
\hline 8 & 0.5073 & 0.0630 \\
\hline 9 & 0.7067 & 09702 \\
\hline 10 & 0.8974 & 0.9629 \\
\hline
\end{tabular}

（2）関数 $F 2$ の解

\begin{tabular}{|c|c|r|}
\hline Family & $x$ & \multicolumn{1}{|c|}{$F 2(x)$} \\
\hline 1 & 0.1007 & .09997 \\
2 & 0.4927 & 0.6862 \\
3 & 0.2805 & 0.6981 \\
4 & 0.2991 & 0.9170 \\
5 & 0.6979 & 0.4590 \\
6 & 0.2903 & 0.8605 \\
7 & 0.5132 & 0.6098 \\
8 & 0.0899 & 0.9266 \\
9 & 0.3148 & 0.7717 \\
10 & 0.1036 & 0.9906 \\
\hline
\end{tabular}




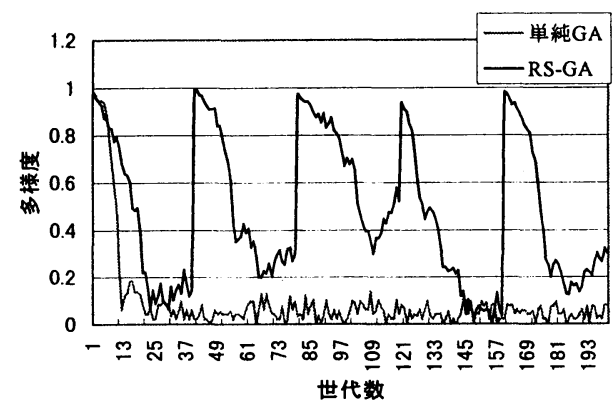

（1）集団サイズ：30 個体

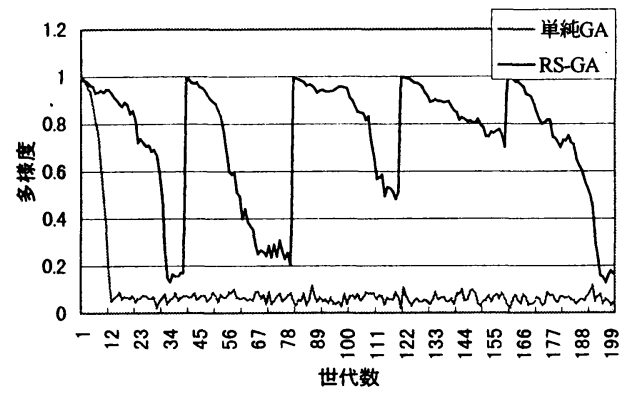

（2）集団サイズ：100 個体

图-7 単純 GA と RS-GA の多様度推移の比較

る. 一方, 関数 $F 2$ については, 図-6(2)および表6 (2) から分かるように, 最小ピーク解 $(\mathrm{x}=0.9)$ の 探索は行えなかったものの, それ以外の 4 つの近似 最適解を探索することに成功している.

最小ピーク解の探索が行えなかった最大の理由と しては, 最小ピーク解の適応度がきわめて小さいこ とが影響していると考えられる. すなわち, 関数 F2 では, 最小ピーク個体の適応度が絶対的に低い ため, 最適解ではないが最小ピーク適応度よりは高 い適応度を有す個体を凌いで存在することができず， その結果, GA 操作の過程で最小ピーク個体が淘汰 される確率が極めて高いためと考えられる.

\section{集団の多様性について}

RS-GA の解探索時における個体の多様度の推移 を理解するために, 関数 F1 の解探索時の多様度の 推移結果を図一7 に示す。なお，同図には比較のた めに単純 GAのそれを併記している.

個体集団の多様性の尺度である多様度は, 個体間 のハミング距離や情報エントロピー 15)，16)，17) の 概念を応用して求めることができる.ここでは, 後 者の情報エントロピーの考え方を用いて算出してい る. 情報エントロピーとは, 物理学におけるエント ロピーの一般概念を “情報量” の視点から捕らえ直 したエントロピー理論のことをいい，現在のその理 論体系には Shannon(Claude Elwood Shannon, US)の

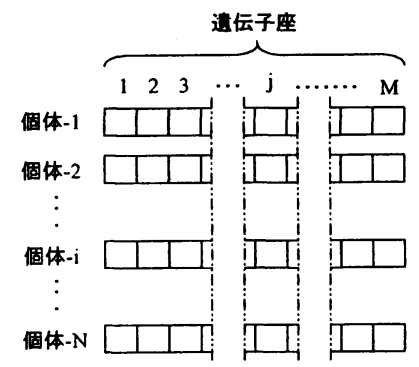

図-8 個体集団の平均情報エントロピーの導出概念図

業績 ${ }^{18)}$ が先駆けであるといわれている.

情報エントロピーの概念を端的に説明する.

今, 事象集合 $X=\left\{X_{1}, X_{2} \cdots, X_{n}\right\}$ とその生起確率 $p=\left\{p_{l}, p_{2} \cdots, p_{n}\right\}$ からなる完全事象系に対する情報 エントロピー $H(p)$ を考えると， $H(p)$ は次式のように 定義される.

$$
H(p)=\sum\left(-p_{k} \log p_{k}\right)
$$

すなわち式(6)は，系のもつ不確定さや複雑さと いった多様化した情報を数量化している．このこと から，事象の情報空間に対してエントロピーの概念 を導入すると，事象が生起 “する”，“しない”と いった明確な情報だけではなく，“どの程度生起す るのか”といったあいまいで抽象的な事象情報まで もが数量化されることが理解できる ${ }^{15)}$.

本研究では, 以上で説明した情報エントロピーの 概念を用いて多様度を計算しているが，具体的には 以下のように行った7).

いま，個体ストリング中に $M$ 個の遺伝子座を持 つ個体が $N$ 個有り，集団を構成している。 その集 団を対象に多様性の数量化（平均情報エントロ ピー）を考える（図-8 参照）。なお，一般に遺伝 子座には特定の遺伝子とその対立遺伝子が出現しう るが，ここでは，遺伝子に 2 進数を用いる場合を例 に解説する（したがって，対立遺伝子は“0” と “1”).

以上のモデルにおいて, 個体の $j$ 番目遺伝子座の 情報エントロピー $H_{j}(N)$ は次式で表される.

$$
H_{j}(N)=\sum_{i=1}^{2}\left(-p_{i j} \log _{2} p_{i j}\right)
$$

ここで， $p_{i j}$ は集団がもつ $j$ 番目の遺伝子座の各対 立遺伝子の出現確率を表し, 次式で定義される.

$p_{i j}=\frac{\text { 遺伝子座 } \mathrm{j} \text { に出現した"0"または"1"の総数 }}{\mathrm{N}}$ 


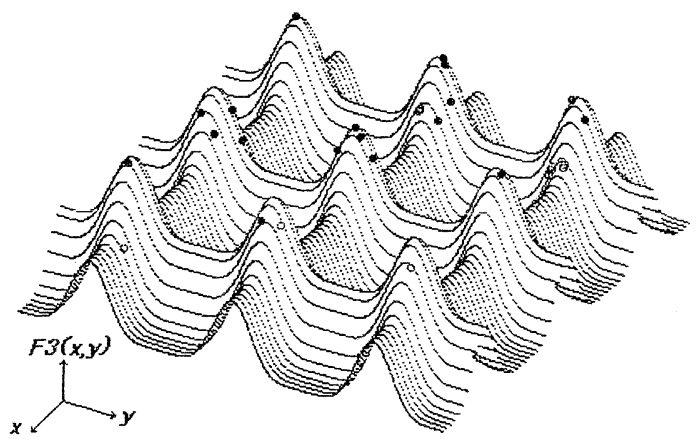

(1) 集団サイズ : 30 個体

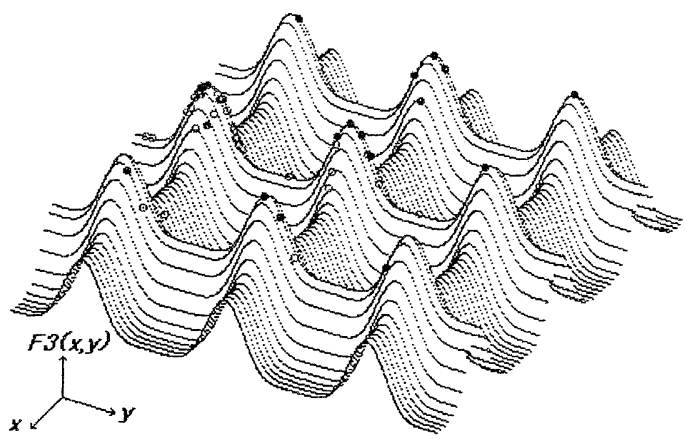

(2) 集団サイズ：100 個体

図-9 関数 F3におけるRS-GA の収束結果

(図中：“Familyエリート”，○：最終 Family 個体)

このように集団の多様度を表す平均情報エントロ ピーは, 式(7)で求められる各遺伝子座の情報エン トロピーの総和平均により次式から求められる.

$$
H(N)=\frac{1}{M} \sum_{j=1}^{M} H_{j}(N)
$$

図-7 は，単純 GA，RS-GA の多様度について, 集団サイズを 30 個体（同図(1)），100 個体（同図 (2)）のそれぞれの場合で比較している。同図(1)お よび(2)から，集団サイズが 30 および 100 個体のと き, 単純 GA が早い世代で多様性を喪失しているの が読みとれる。一方, RS-GA の場合, 同図からわ かるように，特徵ある多様性の推移が認められる。

これは, 単位 Family が一度収束した直後に, 繰り 返し新たに初期集団を産生させ，解探索を続行する ことによる。また，同図から，RS-GA の多様度が Family を更新するほど保たれる傾向にあり，さらに 集団サイズが大きいほど, その傾向は促進されるこ とが同える．このことから，RS-GA では Family エ リートが多様度維持に対して効果的に機能しており, その結果, 探索解の分散性が高く, 大局的な解探索 を行わせることが可能になると言える。また，この 多様度維持は Family 数を増加するほど抑制対象
表-7 RS-GAの探索解（Familyエリート）

(1) 集団サイズが 30 個体の場合

\begin{tabular}{|c|c|r|r|}
\hline Family & $x$ & $y$ & $F 3(x, y)$ \\
\hline 1 & 0.299 & 0.300 & 1.9993 \\
\hline 2 & 0.095 & 0.095 & 1.9633 \\
\hline 3 & 0.277 & 0.307 & 1.6344 \\
\hline 4 & 0.304 & 0.094 & 1.9619 \\
\hline 5 & 0.114 & 0.325 & 1.4858 \\
\hline 6 & 0.088 & 0.490 & 1.8267 \\
\hline 7 & 0.492 & 0.073 & 1.5267 \\
\hline 8 & 0.275 & 0.489 & 1.5358 \\
\hline 9 & 0.294 & 0.281 & 1.7361 \\
\hline 10 & 0.326 & 0.112 & 1.4959 \\
\hline 11 & 0.324 & 0.302 & 1.6431 \\
\hline 12 & 0.318 & 0.130 & 1.2846 \\
\hline 13 & 0.299 & 0.083 & 1.8046 \\
\hline 14 & 0.115 & 0.282 & 1.6295 \\
\hline 15 & 0.508 & 0.304 & 1.9418 \\
\hline 16 & 0.491 & 0.101 & 1.2419 \\
\hline 17 & 0.137 & 0.299 & 1.3402 \\
\hline 18 & 0.093 & 0.320 & 1.7043 \\
\hline & & 平 & 1.6438 \\
\hline & & 標準偏差 & 0.2210 \\
\hline
\end{tabular}

(2) 集団サイズが 100 個体の場合

\begin{tabular}{|c|c|c|c|}
\hline Family & $x$ & $y$ & $F 3(x, y)$ \\
\hline 1 & 0.302 & 0.100 & 1.9970 \\
\hline 2 & 0.309 & 0.287 & 1.8233 \\
\hline 3 & 0.467 & 0.498 & 1.4266 \\
\hline 4 & 0.106 & 0.091 & 1.9153 \\
\hline 5 & 0.099 & 0.301 & 1.9985 \\
\hline 6 & 0.093 & 0.305 & 1.9460 \\
\hline 7 & 0.500 & 0.099 & 1.9993 \\
\hline 8 & 0.297 & 0.504 & 1.9816 \\
\hline 9 & 0.282 & 0.299 & 1.7835 \\
\hline 10 & 0.092 & 0.478 & 1.6474 \\
\hline 11 & 0.320 & 0.501 & 1.7393 \\
\hline 12 & 0.322 & 0.286 & 1.5577 \\
\hline 13 & 0.277 & 0.104 & 1.6583 \\
\hline 14 & 0.492 & 0.302 & 1.9507 \\
\hline 15 & 0.307 & 0.081 & 17267 \\
\hline 16 & 0.301 & 0.130 & 1.4996 \\
\hline 17 & 0.113 & 0.322 & 1.5754 \\
\hline 18 & 0.297 & 0.295 & 1.9750 \\
\hline & & 平 均 & 17.7389 \\
\hline
\end{tabular}

（Family エリート）が堌すことから，解の大局的な 探索性がさらに保証される傾向にある.

\section{Nine-peak 関数の解探索}

前項で RS-GA の解探索性能を，単純 GA のそれ と比較した。 その結果, RS-GA が複数の解探索を 効果的に行いうることが明らかになった。本項では さらに, RS-GA による関数 F3 を対象にした 3 次元 空間に対する解の探索性能を明らかにする.

関数 $F 3$ では，2つの変数 $x, y$ をそれぞれ 9 ビッ トとした個体（遺伝子型）を用いて解探索を行った. また，解空間に対して集団サイズの影響を観るため， 2 種類の集団サイズについて調べた.

图-9 および表一7に，本シミュレーションで得ら れた結果を示す。図-9 は終了条件に達した時点で の探索結果を図示し，表-7 は Family エリート（近 似最適解集合）とその適応度を示している。

同表(1)就よび(2)を比較すると，各集団サイズの 
$\longrightarrow \mathbf{a}$

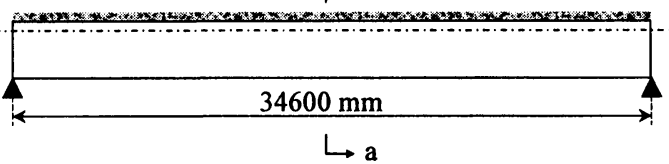

(1) 側面図

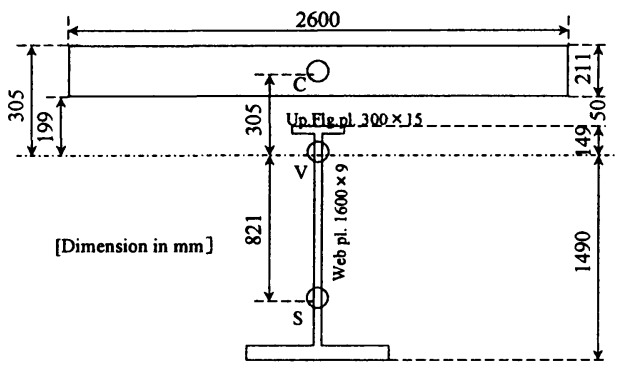

Lw.Flg.pl. $410 \times 24$

(2) a-a 断面

図-10 補強対象モデルの一般図

それぞれで，いくつかの近似最適解を挆索している のが分かる. しかし， 100 個体の方がより適応度の 高い解を探索している（同表中“平均”および “標 淮偏差”を参照）。一般に，単純 $\mathrm{GA}$ では，計算量 が問題になるものの，集団サイズが比較的大きい程， 解の探索精度が向上する傾向にある. したがって, RS-GA においても同様な傾向を示すと言える.さ らに，先述したように Family エリートの機能性に より個体の多様化が促進され，その結果，解の探索 精度が向上するものと考えられる.

本シミュレーションでは, 関数 $F 1, F 2$ よりも解 空間が広く，さらに最適解の数も多いことから，探 索 Family サイズを 18-Family と設定している。いま, 本シミュレーションの設定条件において全通り計算 を行った場合, 約 26 万回の計算量が必要となる.

しかし，本シミュレーションの場合，約 1.6 万回 (集団サイズ : 30 個体) から約 5.4 万回（集団サイ ズ：100 個体）の計算量（全計算回数に対するパー センテージで, 前者が約 $6 \%$ ，後者が約 $20 \%$ ）で以 上の結果が得られている。 また，表-7 から 10Family 前後でおおむね近似最適解を全数探索してい ることが分かる.このことから，RS-GA は比較的 少ない計算量で, 実践的な問題で望まれる近似最適 解を探索できる可能性があると考えられる.

\section{RS-GA の外ケーブル補強設計問題への応用}

前章では, RS-GA の解探索特性を検証した. そ の結果, RS-GA が解空間から複数の近似最適解の
表-8 補強設計対象の構造緒元モデル

\begin{tabular}{|c|c|}
\hline 構造形式 & 単純活荷重合成鈑析 \\
\hline 殷計活荷重 & $L-14$ (二等檟) \\
\hline スパン長 & $34.6 \mathrm{~m}$ \\
\hline $\begin{array}{l}\text { 主銅材 } \\
\left.\text { (部容応力度: } \mathrm{kgf} / \mathrm{cm}^{2}\right)\end{array}$ & 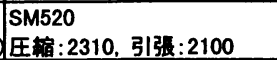 \\
\hline $\begin{array}{l}\text { コンクリート } \\
\text { (許容応カ度 }: \mathrm{kgf} / \mathrm{cm}^{2} \text { ) }\end{array}$ & $\begin{array}{l}\text { 強度: } 360 \mathrm{~kg} / \mathrm{cm}^{2} \\
\text { 红制: } 100, \text { 引張: } 24 \\
\text { ヤング事: } 3.0 \times 10^{5} \mathrm{kgf} / \mathrm{cm}^{2}\end{array}$ \\
\hline $\begin{array}{l}\text { 熙張材 } \\
\text { (許容応力度: } \mathrm{kgf} / \mathrm{cm}^{2} \text { ) }\end{array}$ & $\begin{array}{l}\text { PC銿より線 } \\
\text { 引張: } 5800 \\
\text { ヤング革: } 2.1 \times 10^{6} \mathrm{kgf} / \mathrm{cm}^{2}\end{array}$ \\
\hline
\end{tabular}

探索を行う可能性があることが分かった．そこで本 章では, RS-GA の実践問題への有用性に関する検 討を行うため，著者らがこれまで取り扱ってきた 「合成鈑桁の外ケーブル補強設計問題」を例に用い たケーススタディを実施し， RS-GA の解探索特性 等について 2,3 の考察を行っている.

以下では，まず，外ケーブル補強設計問題の概要 および対象モデル，最適化問題の定式化，そして解 探索のための遺伝子コーディングについて解説し， その後, ケーススタディの結果について述べている.

\section{（1）外ケーブル補強設計問題の概要}

著者らはこれまで, 合成鈑析を対象に外ケーブル プレストレスによる補強設計問題を種々検討してき た ${ }^{19) ， 20)}$. 本研究ではこれまで, 設計荷重に対す るクリティカル断面各部位の応力度状態から, 補強 設計パラメータ（11導入プレストレスカ，(2)緊張材 断面積, (3)緊張材の配置形式·形状など) の決定を 合理的に行う手法を検討してきた．その際，(1)〜 (3) の補強設計パラメータは, 応力度計算のトライアル \&エラーに基づくューザ・ヒューリスティックスに より求解を行うことを提案している，そこで, 本試 行では，ユーザ・ヒューリスティックスの改良手法 として, 補強設計問題を構造最適化問題として定式 化し, その際に前章で提案した RS-GA を, 補強設 計パラメータの最適解探索手法として応用している.

\section{（2）最適化問題への定式化と寈伝子コーディング}

\section{a) 補強設計対象}

本ケーススタディでは, スパン $=34.6 \mathrm{~m}$, 設計活 荷重=L-14 で設計された既設の単純活荷重合成鈑析 橋（二等橋， 3 主桁）の中析を補強設計モデルとし ている（図-10および表-8 参照）.

\section{b) 最適化問題への定式化}

本研究における外ケーブルプレストレス補強の目 的は，旧設計活荷重（例，L-14，L-20 など）で設 計された合成鈑析（既設）に対し， B 活荷重載荷で クリティカル断面に発生する超過応力度を, 外ケー ブル方式によりプレストレスカを導入することで相 
殺する．このことから補強設計対象は，補強目的を 達成するために必要な導入プレストレスカおよびそ れを可能にする緊張材などとなる．したがって本試 行では，これまで同様，取り扱う補強設計パラメー タとして(1)導入プレストレスカ, (2)緊張材断面積,

(3)緊張材の配置形式・形状を仮定し，さらに外ヶー ブルプレストレス技術と組合せて適用が考えられる (4)木版上面増厚を, 新たな補強設計パラメータに追 加している.

\section{$\diamond$ 目的関数}

本試行では，目的関数をクリティカル断面の「下 フランジ」「上フランジ」および休版」それぞれ の縁応力を対象に, 以下のように定義している.

\section{・下フランジ縁応力度}

本試行では, 卓越する曲げ応力に対して桁構造の 設計が決まると仮定する．したがって，本試行では 設計荷重 (導入プレストレスカ, 増加プレストレス 力, $\mathrm{B}$ 活荷重) 満載時におけるクリティカル断面の 下フランジ縁応力度に対して行う応力度照查を第一 義とする．下フランジ縁応力度に関する目的関数 $f_{s 1}$ を次式のように定義する.

$$
f_{s 1}=\left(1-\frac{\left|\sigma_{s t a}-\sigma_{s 1}\right|}{\sigma_{s t a}}\right) \cdot n_{s 1} \rightarrow 1.0
$$

ここで, $\sigma_{s t a}$ :主鋼材の許容引張強度, $\sigma_{s 1}$ :下フランジ 縁応力度 (設計荷重满載), $n_{s 1}$ :ペナルティ倸数. ただし, $\sigma_{s t a} \geq \sigma_{s 1}$ の 時 $\left\{n_{s 1} \mid n_{s 1}=1.0\right\}, \sigma_{s t a}<\sigma_{s 1}$ の 時 $\left\{n_{s 1} \mid 0.0<n_{s 1}<1.0\right\}$.

式(10)より， $\sigma_{s t a}$ と $\sigma_{s 1}$ がバランスすることで超 過応力度 $\Delta \sigma_{e x}\left(=\sigma_{s t a}-\sigma_{s 1}\right)$ は $\Delta \sigma_{e x}=0$ となり, そ の結果, $f_{s 1}=1.0$ となるように目的関数を定義して いる. また $\sigma_{s t a}<\sigma_{s 1}$ の時, $\Delta \sigma_{e x}$ が発生するため にその解を実行可能解に採用することはできない. しかし，その際の解（個体）を全く否定してしまう と, 結果的に有効解の探索を損なう恐れがある. こ のことから, 本試行ではその場合を想定して, 式 (10)中に示したペナルティ倸数を設定し, $\Delta \sigma_{e x}$ が 発生しない場合よりも評価值を低減する処置を採る ようにしている. なお， $\Delta \sigma_{e x}$ が発生する時の $n_{s 1}$ は, ユーザが任意に調整する.

\section{・上フランジ緣応力度および床版上面応力度}

外ケーブルプレストレス補強は，原則的に，設計 活荷重を相殺するように, それとは逆向きの曲げ応 力や橋軸方向への軸圧縮力を補強対象に作用させる. このとき以下について注意が必要になる. すなわち, プレストレスカの軸方向成分により, 中立軸付近の
上フランジは圧縮応力を発生させる.このため, 下 フランジ同様, 死・活荷重により既にクリティカル な状態にあると思われる上フランジは，さらに圧縮 応力を発生させることになる，一方，床版上面に対 しては，プレストレスカの導入に際して制約を考慮 する必要がある（これについては次項で述べる）以 外に, 上フランジ同様, 設計荷重満載時に下フラン ジの応力状態を満足しながら，床版コンクリートの 許容強度内に発生応力を収める必要がある。

以上を整理すると，下フランジの超過応力状態を 改善する目的のプレストレスカは, 同時に, 上フラ ンジや床版コンクリートに対して負の作用をもたら す危険性もある. したがって，応力度照查に基づく 補強設計解の算出プロセスに, 下フランジ縁応力度 の評価だけでは不十分になる.

このことから，上フランジ縁応力度および床版上 面応力度に対する目的関数を次式のように定義する.

$$
\begin{aligned}
& f_{s 4}=\left\{\begin{array}{cc}
1 & \left(\sigma_{s c a} \geq \sigma_{s 4}\right) \\
\left(1-\frac{\sigma_{s 4}-\sigma_{s c a}}{\sigma_{s c a}}\right) \cdot n_{s 4} & \left(\sigma_{s c a}<\sigma_{s 4}\right)
\end{array} \rightarrow 1.0\right. \\
& f_{c 2}=\left\{\begin{array}{cc}
1 & \left(\sigma_{c c a} \geq \sigma_{c 2}\right) \\
\left(1-\frac{\sigma_{c 2}-\sigma_{c c a}}{\sigma_{c c a}}\right) \cdot n_{c 2} & \left(\sigma_{c c a}<\sigma_{c 2}\right)
\end{array} \rightarrow 1.0\right.
\end{aligned}
$$

ここで, $\sigma_{s c a}, \sigma_{c c a}:$ それぞれ主鋼材およびコンクリート の許容圧縮応力度, $\sigma_{s 4}, \sigma_{c 2}$ :それぞれ上フランジおよび 床版上面の縁応力度 (設計荷重満載) $, n_{s 4}, n_{c 2}$ :それぞれ 上フランジおよび床版に関するペナルティ係数.

式(11)，(12)より分かるように，上フランジおよ び床版に対する目的関数は, それぞれの発生応力度 が許容応力度内で有れば最大値”1.0”をとる. 一方, 許容値を上回るような場合では，目的関数は”1.0" 未満の値をとり, さらに下フランジ同様, 有効解の 探索を損なう恐れを考虑してペナルティ係数を用い た処理により，目的関数を低堿させることで当該個 体に対する淘汰圧力を促している. なお， $n_{s 4}, n_{c 2}$ は $0.0 〜 1.0$ までの値をとりユーザが任意に調整する。

\section{制約条件}

制約条件には「導入プレストレスカ」および「緊 張材応力」を対象に，以下のような定義をしている。

\section{- 導入プレストレスカ}

床版上面は，導入プレストレスカの負曲げ効果に より引張応力が発生する.このため, 床版はクラッ ク等の危険性が奬念される.そこで，このことを考 慮するために以下のような不等式を定義している.

$$
P_{t c_{-} \max }-P_{t} \geq 0
$$


ここで, $P_{t c_{-} \max }$ : プレストレスカ導入時に床版上面の許 容引張強度を制約とした時の導入可能最大プレストレス カ, $P_{t}$ : 当該導入プレストレスカ.

\section{- 緊張材応力}

緊張材には「導入プレストレスカ」および「増加 プレストレスカ」により引張応力が発生する. 特に 増加プレストレスカは, B 活荷重載荷により生じる 他に，床版增厚の施工順序によっては，床版増厚に よる増加死荷重により発生することも考えられる.

そこで, 本試行では床版増厚の施工順序を, 導入プ レストレッシング終了後に床版增厚工を実施すると 仮定している.このことから，緊張材応力を考慮す るために，以下の不等式を定義している.

$$
\sigma_{\text {tena }}-\frac{P_{t}+\Delta P_{t}}{A_{t}} \geq 0
$$

ここで, $\sigma_{\text {tena }}$ : 熙張材の許容引張強度, $\Delta P_{t}$ : 増加プレス トレス力 (床版増厚荷重および $\mathrm{B}$ 活荷重載荷時), $A_{t}$ : 緊 張材断面積.

適応度関数

以上で定義した目的関数および制約条件からなる 制約条件付き最適化問題を，次式のような無制約の 最適化問題に変換し，RS-GA を使った解探索での 適応度関数として定義している.

$$
f_{\text {all }}=\frac{n_{P_{1}}}{3}\left(f_{s 1}+f_{s 4}+f_{c 2}\right) \rightarrow 1.0
$$

ここで, $n_{P_{t}}$ : 緊張材に関するペナルティ係数. ただし $n_{P_{t}}$ は, $P_{\text {sc } \max } \geq P_{t}$ および $\sigma_{\text {tena }} \geq\left(P_{t}+\Delta P_{t}\right) / A_{t}$ の 時 $\left\{n_{P_{t}} \mid n_{P_{t}}=1.0\right\}$ を採 $り, \quad P_{t c_{-} \max }<P_{t}$ およ び $\sigma_{\text {rena }}<\left(P_{t}+\Delta P_{t}\right) / A_{t}$ の 時 $\left\{n_{P_{t}} \mid n_{P_{t}}=0.5\right\}$ を採る.

式(15)は，3つの目的関数および緊張材に関する ペナルティ係数を考虑して定義した式である.また， 同式は正規化を行っているので， $f_{\text {all }}$ は $0.0 \sim 1.0$ の 值を採る。したがって $f_{\text {all }}=1.0$ に近いほど適応度 が高い（即ち近似最適解）ことを意味する.

$n_{P_{1}}$ の意味について少し説明を加えると，外ケ一 ブルプレストレス補強においては，緊張材が最重要 部材である為, 緊張材が自身の許容引張強度を設計 荷重時満載時の発生応力 $\left(=\left\lceil P_{t}+\Delta P_{t}\right\rfloor\right.$ と絶対值が等

価）が上回る場合，クリティカル断面のどの部位よ りも先に使用限界状態に到達すると定義している.

したがって，緊張材はクリティカル断面の各部位の 応力状態に関わらず，適応度関数に対し専制的な負 の影響を与える意味を持つ。
、探索範囲 (その他の制約条件)

その他の探索範囲制約を以下に示す.

- 導入プレストレスカ $P_{t}(\mathrm{tf})\left\{P_{t} \mid 10.0 \leqq P_{t} \leqq 265.0\right\}$.

- 緊張材断面積 $A_{t}\left(\mathrm{~cm}^{2}\right)\left\{A_{t} \mid 1.0 \leqq A_{t} \leqq 32.5\right\}$.

- 緊張材の配置形式を QUEEN-Post 形式とし, 定着 端位置は桁高さ内で，かつ，合成断面中立軸上を 最小偏心量 $(e=0.0)$ とする.

・QUEEN-Post 形式におけるケーブル偏向部位置は, 下フランジ位置に固定（桁下クリアランスに余裕 がない場合）もしくは最大 $\mathrm{y}_{\mathrm{sl}}$ （合成断面中立軸 位置から下フランジまでの距㒕）の張出しを認め る（桁下クリアランスに余裕がある場合）。

・緊張材の許容折り曲げ角度は 10 度（鋼線系）.

\section{c）遺伝子コーディング}

RS-GA を適用して解探索を行うために，補強設 計パラメータを個体ストリング（遺伝子型）にコー ディングする必要がある. なお，本試行では 2 進数 遺伝子型を用いた。

本試行で基本的に対象とした補強設計パラメータ は, (1)導入プレストレスカ, (2)緊張材断面積, (3)祭 張材配置形式·形状，そして(4)床版増厚值である. したがって，上述した探索範囲を踏まえて各補強設 計パラメータを次のように設定した（図-11参照）.

(1)は，0.5(tf)を離散ピッチとし，10.0〜265.0(tf)ま での範囲を離散化した（即ち 9 ビット長で表現）. (2)は，緊張材断面積の離散ピッチを $0.5\left(\mathrm{~cm}^{2}\right)$ とし， $1.0 \sim 32.5\left(\mathrm{~cm}^{2}\right)$ までの範囲を離散化した（即ち 6 ビット長で表現）。(3は，配置形式を遺伝子として 取り扱わず任意に選択する。一方, 配置形状は定着 端，偏向部が桁断面方向において取り得る範囲をそ れぞれ 8 分割と 16 分割の離散量とした（即ちそれ ぞれを 3 ビット長，4 ビット長で表現）. (4)は，あ まり小さな変量は実践的でない. そこで本試行では, 增厚最小值および最大値をそれぞれ $3.0(\mathrm{~cm}), \Delta$ Tc_max と仮定し，その間を 4 分割に離散化した

(即ち 2 ビット長で表現) ここで， $\Delta \mathrm{Tc}$ _max は, 増厚後の新合成断面中立軸が床版内にはいることを 認めない条件から算出している. また，増厚床版材 は旧床版材と同等と仮定した（図-12 参照）.

以上のコーディングに関して，これまでの研究か ら(1)（導入プレストレスカ）および(2)（緊張材断面 積）の各補強設計パラメータが, 式(15)で定義した 適応度関数に与える影響が比較的大きいと明らかに 予測できたので，それらにおける離散化を比較的細 かく行っている.さらに，(3)の定着部および偏向部

(それぞれ桁断面方向）についても同様に，式(15) に対して，(1)，(2)よりも比較的ロバストな性質があ ると予測できたので，それぞれを 8 および 16 分割 


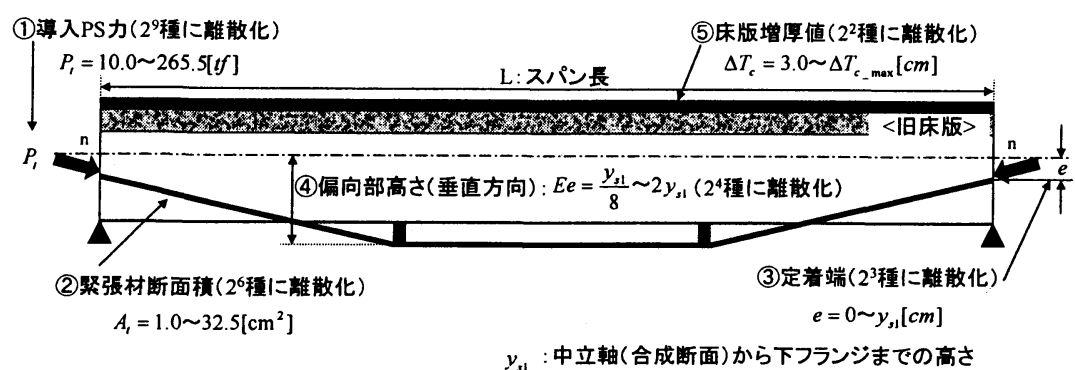

図-11 外ケーブルプレストレス補強設計パラメータ

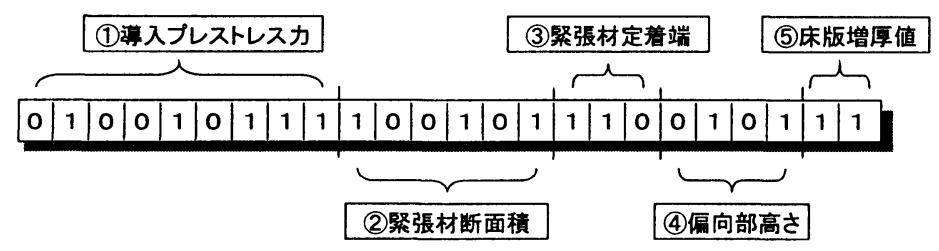

図-12 補強設計パラメータの個体コーディング（2 進数）例

の離散量としている. なお, 偏向部の軸方向位置に ついては, 緊張材の許容偏向角度の制約等を考慮し て，スパン $1 / 3$ および $2 / 3$ 点に固定している.

d) GA 戦略パラメータ

本試行での RS-GA 戦略パラメータを表-9 に示す. 集団サイズの決定には計算効率を考慮して, 次式 のような釣合い式を定義する.

$$
S_{p o p} \times \mathrm{G}=\beta \times 2^{L_{s t}}
$$

ここで, $S_{p o p}$ :集団サイズ, $G$ :単位 Family 世代数, $\beta$ : 全通り計算回数に対する $\mathrm{GA}$ による収束到達までの総計 算回数の割合, $L_{s t}$ : 個体ストリング長.

式(16)の左辺は, 単位 Family 終了までの総計算回 数を表し, 右辺は, 全数計算回数に $\beta$ を乗じた値を 示している. この釣合い式から，当該問題における 集団サイズ $S_{p o p}$ (整数) を次式より算定している.

$$
S_{p o p}=I N T \cdot\left(\frac{\beta \times 2^{L_{\prime \prime}}}{\mathrm{G}}\right)
$$

同式中"INT[*]”は，実数”*”の小数部を切り捨て 整数化することを意味する.なお，本試行では， $\beta=0.1$ を用いている.

交叉方法は，交叉効率を考慮してシャッフリング 交叉 ${ }^{21)}$ を用いた。この方法は個体遺伝子座を シャッフルすることにより，例えば，単純交叉が簡 単に任意の多点交叉と同等な意味を持つ。一般に,

\begin{tabular}{|c|c|}
\hline & RS-GA \\
\hline $\begin{array}{l}\text { 集団サイス } \\
\text { 終了条件 }\end{array}$ & $\begin{array}{c}\text { 算出式により施 } \\
\text { 10 Family(30世代/Family) }\end{array}$ \\
\hline 遗伝子型 & 2進数("0" or"1") \\
\hline 個体ストリングス長 & 可変 \\
\hline 交叉確率 & $20 x$ \\
\hline 突然変異率 & $1 \%$ \\
\hline 選択操作 & ランク戦略 \\
\hline 交叉操作 & シャッフリング交叉 \\
\hline 突然変異操作 & 任意遺伝子座の1-bit反転 \\
\hline
\end{tabular}

表-9 本試行での RS-GA 戦略パラメータ

変数が多元に渡る実践問題では, 個体のコーディン グ状態如何で交叉効率が低下することが懸念される （所謂 “コーディングの癖”）．シャッフリング交 叉はこのような問題に対し，特に効果を発揮する.

\section{（3）ケーススタディーの結果と考察}

本試行では, 2 種類の試行ケース（試行-1, 試行2) を行っている. 試行-1 では, 緊張材の配置形式 を QUEEN-Post 形式とし，緊張材の定着端を中立軸 上 $(e=0.0)$, 偏向部の位置をスパン $1 / 3$ および $2 / 3$ 点, かつ下フランジ位置 $\left(E e=y_{s l}\right)$ を一定とした状 態において「(1)導入プレストレスカ」「(2)緊張材断 面積」の值を探索した. 一方, 試行-2 では, 試行-1 の条件に, 毉張材の定着端および偏向部（いずれも 桁断面方向）と，さらに床版増厚の項を補強設計パ ラメータに加えて「(1)導入プレストレスカ」「(2)緊 張材断面積」「(3)配置形状(定着端, 偏向部高さ)」 「(4)床版増厚値」の解を探索した（図-11 参照）。 
表-10 試行-1の結果

\begin{tabular}{|c|r|r|r|r|}
\hline Family & 薄入PS力(tf) & 断面積 $\left(\mathrm{cm}^{2}\right)$ & $\begin{array}{c}\text { 下フランジ余剩 } \\
\text { 伈 }\left(\mathrm{kgf} / \mathrm{cm}^{2}\right)\end{array}$ & 適応度 \\
\hline 1 & 74.0 & 16.0 & 27 & 0.9957 \\
2 & 72.0 & 14.5 & 8 & 0.9987 \\
3 & 69.5 & 19.0 & 7 & 0.9988 \\
4 & 87.5 & 29.0 & 160 & 0.9746 \\
5 & 93.0 & 25.5 & 186 & 0.9705 \\
6 & 126.5 & 24.5 & 406 & 0.9356 \\
7 & 85.5 & 24.5 & 132 & 0.9790 \\
8 & 66.0 & 24.0 & 1 & 0.9999 \\
9 & 86.0 & 18.5 & 116 & 0.9816 \\
10 & 112.0 & 27.0 & 317 & 0.9497 \\
\hline & & & 平 均 & 0.9784 \\
\hline
\end{tabular}

以下では, 試行-1, 試行-2 の順に考察結果を述べ る.なお, 本試行では式(2)に示す適応度抑制関数 の各パラメータは, 本試行の予備実験の結果を踏ま えて, $d_{0}=5, \alpha=0.25$ を採用している.

\section{a) 試行-1の結果と考察}

表-10 に, RS-GA で得られた全 Family エリート （複数の探索解）を示す. 試行-1では，「(1)導入プ レストレスカ」と「(2)緊張材断面積」の組合せの中 から，式(15)で定義した適応度関数を満足する解を 探索している．同表から分かるように，適応度が 0.95 以上を示す (1)，(2)）の組合せ解が多数得られ ている. QUEEN-Post 形式による外ケーブルプレス トレス補強では，「導入プレストレスカ」と「緊張 材による構造全体系の曲げ剛性の向上」の 2 つの要 因により補強効果が出現する.この内, 緊張材断面 積が大きいほど緊張材の引張剛性が高いため, 後者 が効果的におこる。このことから，本試行のように 緊張材の許容引張強度を使い切るような経済設計を 考えなければ，表-10 で示したように高適応度を示 寸解の組合せが複数存在することは, 妥当な結果と 考えることができる.

試行-1 の場合，解探索空間における (1)，(2)）の 組合せ解の総数は約 3.27 万組あり，そのうち，全 通り計算の結果から適応度が 1.0 となる最適解の組 合せは 51 組存在することが明らかとなっている

(表-11 参照)．その最適解集合は, 緊張材の許容 引張強度を使いきる組合せ解（表-11中 No.1）から， その許容引張強度がかなり余る組合せ解（同表中 No.51）までの間に, 適応度関数を 1.0 に保つ複数 の組合せ解の集合である．図-13 に RS-GA による 探索解と 51 組の最適解をプロットして考察すると, 先述した通り RS-GA では，4つの Family で近似最 適解を探索していることが分かる（表-10 中 Family-1〜3 および 8 の解）。一方，それ以外の探 索解は設計空間的に最適解曲線よりは遠く離れてお
表-11 全通り計算結果から求めた最適解集合

\begin{tabular}{|c|c|c|c|c|c|}
\hline & 取道 & 菓合 & 7 & 度 $=1.0)$ & \\
\hline No & $\begin{array}{c}\text { 尊入PS力 } \\
\text { [tf] }\end{array}$ & $\begin{array}{l}\text { 新面樌 } \\
{\left[\mathrm{cm}^{2}\right]}\end{array}$ & No & $\begin{array}{c}\text { 尊入PS力 } \\
\text { [tf] }\end{array}$ & 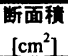 \\
\hline 1 & 74.50 & 7.5 & 27 & 68.00 & 20.5 \\
\hline 2 & $\downarrow$ & 8.0 & 28 & 67.50 & 21.0 \\
\hline 3 & 74.00 & 8.5 & 29 & $\downarrow$ & 21.5 \\
\hline 4 & 73.50 & 9.0 & 30 & 67.00 & 22.0 \\
\hline 5 & $\downarrow$ & 9.5 & 31 & 1 & 22.5 \\
\hline 6 & 73.00 & 10.0 & 32 & 66.50 & 23.0 \\
\hline 7 & $\downarrow$ & 10.5 & 33 & $\downarrow$ & 23.5 \\
\hline 8 & 72.50 & 11.0 & 34 & 66.00 & 24.0 \\
\hline 9 & $\downarrow$ & 11.5 & 35 & $\downarrow$ & 24.5 \\
\hline 10 & 72.00 & 12.0 & 36 & $\downarrow$ & 25.0 \\
\hline 11 & $I$ & 12.5 & 37 & 65.50 & 25.5 \\
\hline 12 & 71.50 & 13.0 & 38 & $\downarrow$ & 26.0 \\
\hline 13 & $\downarrow$ & 13.5 & 39 & 65.00 & 26.5 \\
\hline 14 & 71.00 & 14.0 & 40 & $\downarrow$ & 27.0 \\
\hline 15 & $\downarrow$ & 14.5 & 41 & 64.50 & 27.5 \\
\hline 16 & 70.50 & 15.0 & 42 & $\downarrow$ & 28.0 \\
\hline 17 & $\downarrow$ & 15.5 & 43 & 64.00 & 28.5 \\
\hline 18 & 70.00 & 16.0 & 44 & 1 & 29.0 \\
\hline 19 & $\downarrow$ & 16.5 & 45 & $\downarrow$ & 29.5 \\
\hline 20 & 69.50 & 17.0 & 46 & 63.50 & 30.0 \\
\hline 21 & $\downarrow$ & 17.5 & 47 & $\downarrow$ & 30.5 \\
\hline 22 & 69.00 & 18.0 & 48 & 63.00 & 31.0 \\
\hline 23 & $\downarrow$ & 18.5 & 49 & $\downarrow$ & 31.5 \\
\hline 24 & 68.50 & 19.0 & 50 & 62.50 & 32.0 \\
\hline 25 & $\downarrow$ & 19.5 & 51 & & 32.5 \\
\hline 26 & 68.00 & 20.0 & & & \\
\hline
\end{tabular}

り，そのため適応度が比較的低くなっていると考え られる. しかし，これらの解は適応度が低いものの， 応力的には余裕を持って設計目標を満足しているこ とから，実行可能解として有意な解であると言える このように, RS-GA による解の探索では, 複数の 最適解（近似最適解を含む）の探索だけでなく複数 の実行可能解をも同時に探索可能であることから， RS-GA による解情報を設計プロセスに活用した， 柔軟な技術的検討作業の効率化が可能と考えられる. b) 試行-2の結果と考察

試行-2 は，試行-1 の条件に「定着偏心」「偏向 部高さ」および「床版増厚」を補強設計パラメータ に加えて解探索を行った。 その結果を表-12 に示す. 床版増厚を施した場合，床版増厚による補強効果の ため, 試行-1 の結果に比べ全般的に「(1)導入プレ ストレスカ」と「(2)緊張材断面積」の值が，僅かな がら小さい解が探索されていることが分かる．また 下フランジの余剩応力が試行-1 の場合と比べ大き いのは, 補強設計モデルが床版増厚を考慮しなくて も，外ケーブルプレストレス補強のみで十分補強設 計案が算出されるものであったため，床版増厚を考 慮することによって, 余裕のある補強設計が行われ ているためと考えられる.

\section{（4） RS-GA の有用性}

以上の試行結果より，外ケーブル補強設計問題に 対して RS-GA は，有意な近似最適解を多数探索し 得ることが分かった。これらの解を探索するには， 
表-12 試行-2の結果

\begin{tabular}{|c|c|c|c|c|c|c|c|}
\hline Family & 望入PS力（tf） & 断面程 $\left(\mathrm{cm}^{2}\right)$ & 定着端位置 & $\begin{array}{l}\text { 偳向部 } \\
\text { 断面方向) }\end{array}$ (标 & $\begin{array}{c}\text { 床版增厚值 } \\
(\mathrm{cm})\end{array}$ & $\begin{array}{l}\text { 下フランジ余剩 } \\
\text { 応カ }\left(\mathrm{kgf} / \mathrm{cm}^{2}\right)\end{array}$ & 逼応度 \\
\hline 1 & 10.0 & 32.5 & $\mathrm{e}=(0 / 8) \mathrm{y}_{\mathrm{sl}}$ & $\mathrm{Ee}=(1 / 8) \mathrm{y}_{\mathrm{sl}}$ & 3 & 382 & 0.9393 \\
\hline 2 & 10.5 & 6.5 & $\mathrm{e}=(7 / 8) \mathrm{y}_{\mathrm{sl}}$ & $\mathrm{Ee}=(11 / 8) \mathrm{y}_{\mathrm{sl}}$ & 6 & 290 & 0.9539 \\
\hline 3 & 41.5 & 20.0 & $\mathrm{e}=(3 / 8) \mathrm{y}_{\mathrm{sl}}$ & $\mathrm{Ee}=(4 / 8) \mathrm{y}_{\mathrm{sl}}$ & 3 & 437 & 0.9307 \\
\hline 4 & 87.5 & 23.0 & $\mathrm{e}=(4 / 8) \mathrm{y}_{\mathrm{sl}}$ & $\mathrm{Ee}=(12 / 8) \mathrm{y}_{\mathrm{sl}}$ & 3 & 618 & 0.9019 \\
\hline 5 & 57.0 & 25.5 & $e=(6 / 8) y_{s l}$ & $\mathrm{Ee}=(13 / 8) \mathrm{y}_{\mathrm{sl}}$ & 3 & 550 & 0.9127 \\
\hline 6 & 70.0 & 18.5 & $e=(4 / 8) y_{s l}$ & $\mathrm{Ee}=(8 / 8) \mathrm{y}_{\mathrm{sl}}$ & 3 & 524 & 0.9168 \\
\hline 7 & 64.5 & 23.0 & $\mathrm{e}=(0 / 8) \mathrm{y}_{\mathrm{sl}}$ & $\mathrm{Ee}=(5 / 8) \mathrm{y}_{\mathrm{sl}}$ & 6 & 367 & 0.9417 \\
\hline 8 & 98.0 & 29.0 & $\mathrm{e}=(5 / 8) \mathrm{y}_{\mathrm{sl}}$ & $E e=(11 / 8) y_{s l}$ & 6 & 522 & 0.9171 \\
\hline 9 & 61.5 & 21.5 & $\mathrm{e}=(1 / 8) \mathrm{y}_{\mathrm{sl}}$ & $\mathrm{Ee}=(5 / 8) \mathrm{y}_{\mathrm{sl}}$ & 3 & 476 & 0.9245 \\
\hline 10 & 124.0 & 24.0 & $\mathrm{e}=(7 / 8) \mathrm{y}_{s \mathrm{sl}}$ & $\mathrm{Ee}=(14 / 8) \mathrm{y}_{\mathrm{sl}}$ & 3 & 759 & 0.8796 \\
\hline & & & & & & 平均 & 0.9218 \\
\hline & & & & & & 標準偏差 & 0.0214 \\
\hline
\end{tabular}

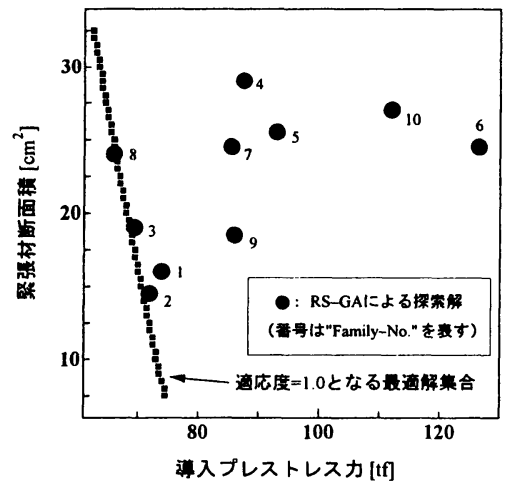

図-13 最適解集合とRS-GA による探索解の関係

各種の最適化パラメータ（RS-GA，ペナルティ倸数 など）のチューニングが求められるが，現在のとこ ろこの方法には合理的な考えが見あたらない.した がってそのパラメータのチューニングは, 当該問題 の典型的ケースを予備実験として何パターンか試み, その結果から経験的に設定することが望ましい.

また本試行では，これらの解集合は本試行で用い た計算機（CPU の内部クロック周波数 $=300 \mathrm{~Hz}$ ）で 比較的短時間で得られており（試行-1 で約 $3 \mathrm{~min}$, 試行-2 で約 $5 \mathrm{~min}$ ）, 計算効率性は高いと考える. なお，RS-GA を用いた最適化プロセスでは，応力 解析で適用する数值解析法に依存して, 計算時間が 左右されるのは論をまたない。

以上から, 手法利用者は, 最適化問題の定式化, 各種パラメータのチューニングに要する労力, 出力 に対する要求精度などを十分に勘案するのが望まし い. しかし， RS-GA は GA ベース手法特有の汎用性 を有することから，この作業は比較的容易であると 思われる。

\section{5. まとめ}

本研究では, 複数の最適解探索を目的に, 単純 $\mathrm{GA} ヘ ゙ ー ス の$ 連鎖探索型遺伝的アルゴリズム（RSGA）を提案した. 本論文では RS-GA の解説， 2 次 元および 3 次元の多峰性関数を用いた RS-GA のシ ミュレーションから，RS-GA の解探索特性を検証 した. さらに, RS-GA のケーススタディとして外 ケーブル補強設計問題を対象にその有用性を検討し た.

本章では, 本研究で得られた知見を要約し, 本論 文のまとめとする.

(1) 単純 $\mathrm{GA}$ を連続的に実行させ, 複数の最適解を 探索する手法として RS-GA を提案した. RS-GA は, 比較的アルゴリズムの理解が容易と考えられる単純 GA を僅かに改良することで, 単純 GA で㲘念され る初期収束を緩和し, さらに大域的な複数の解探索 を可能にすることを目的としている.

(2) RS-GA の解探索特性を把握するため, 2 次元お よび 3 次元の多峰性関数を例に性能検証を行った. その結果, 単純 GA は概ね一つの近似最適解に収束 する一方, RS-GA は大域的な解探索性により, 複 数の近似最適解をほぼ全て挆索する結果を得た.

（3) 集団サイズが大きいほど，解の探索精度は高い。 また，個体の抑制関数は，八ミング距離に対するし きい值, 抑制パワーなどの RS-GA 特有の戦略パラ メータをチューニングする必要がある.

(4) “Family エリート” は “Family” の更新回数に 比例して増加する．そのため “Family” が更新する ほど，当該 “Family”における個体は，抑制対象の “Family エリート”との類似度を全て測定する必要 があり, その結果, 計算時間の增加に至る.

(5) 外ケーブル補強設計問題を例に試みたシミュ レーション結果から, 最適化問題の定式化に問題が なければ, RS-GA は構造最適化問題に有意な複数 
の近似最適解を提示可能である．また，実践的最適 化問題の求解には，定式化に RS-GA を意識した工 夫が必要である。

(6) RS-GAを使って行う実践的な最適化問題の解法 には可能性がある．例えば，制約条件を緩くした状 態で複数の解を探索させ，その解をヒントにして正 解を吟味する求解手法は，ユーザの技術検討プロセ スを支援すると言える。即ち，ユーザがRS-GA解を ヒントにして, 以降の操作で解空間を照査する場合 など，様々な場面でこれらの設計案を参照データと して活用することが期待できる.

\section{参考文献}

1) Goldgerg,D. E. : Algorithms in Seach, Optimization, and Machine Learning, Addison-wesley, 1989.

2) 北野宏明：遺伝的アルゴリズム，産業図書， 1993.6 .

3) 構造工学委員会 $\mathrm{AL}$ (人工生命)技術の構造システム最 適化一の応用に関する研究小委員会 : 新しい構造シ ステム最適化手法一人工生命技術の応用一，土木学 会論文集,No.543/ I -36, pp.1-18, 1996.7.

4） Colin R. Reeves 編，横山隆一，奈良宏一，佐藤晴夫， 鈴木昭男, 萩本和彦, 陳洛南訳: モダンヒューリス ティックスー組合せ最適化の先端手法, 日刊工業新 聞社, 1997.6.

5）森一之, 築山 誠, 福田豊生 : 多様性をもつ免疫 的アルゴリズムの提案と負荷割当て問題への応用,電 気学会論文誌, Vol.113-C, No.10, pp.872-878, 1993.

6) 筒井茂義 : Forking GA一個体群探索分岐型遺伝的ア ルゴリズム，遺伝的アルゴリズム(2)（北野宏明編）， 産業図書, pp.35-67, 1995.5.

7）森一之, 筑山 誠, 福田豊生: 免疫アルゴリズム による多峰性関数最適化,電気学会論文誌, Vol.117C, No.5, pp.593-598, 1997.

8）和田健之助・土居洋文：『遺伝的アルゴリズムと免疫 システム論』の特集にあたって, 数理科学, pp.5-7, 1992.11.
9) 北野宏明 : 人工生命の進化·発生·学習の統合, 数理 科学, pp.24-31, 1992.11 .

10) 米澤保雄 : 遺伝的アルゴリズムー進化理論の情報科 学一, 森北出版, 1994.10.

11) 例えば, 田村 亨, 杉本博之, 上前孝之：遺伝的ア ルゴリズムの道路整備順位決定問題への適用，士木 学会論文集,No.482/IV-22, pp.37-46, 1994.1.

12) 例えば, 杉本博之, 鹿 泫麗, 山本洋敬 : 離散的構 造最適設計のための GA の信頼性向上に関する研究, 土木学会論文集,No.471/ I -24, pp.67-76, 1993.7.

13）古田均, 川村幸男, 有村英樹, 児島哲朗, 川岡靖 司, 田中正明, 金吉正勝 : 斜張橋架設精度管理 $の$ GA の応用, 構造工学論文集,Vol.45A, pp.443-451, 1999.3.

14) 例えば, 長屋秀和, 黒木勇人, 香月 智, 佐藤紘志, 松島 学: 対話型トラス構造最適設計への遺伝的ア ルゴリズムの応用，構造工学論文集, Vol.45A, pp.433-442, 1999.3 .

15）国沢清典：情報理論 I ーエントロピーと情報量一, 情報科学講座 $A \cdot 2 \cdot 4$, 共立出版, 1983.6 .

16）梅垣壽春, 大宅雅則 : 確率論的エントロピー一情報 理論の函数解析的基礎 1 -, 情報科学講座 $\mathrm{A} \cdot 2 \cdot 6$, 共立出版, 1983.12 .

17) 大矢雅則 : エントロピー・その様々な顔つき, 数理 科学, No.294, pp.5-13,1987.12.

18）国沢清典, 梅垣寿春 編 : 情報理論の進歩ーエントロ ピー理論の発展一, 現代科学選書, 岩波書店, 1965.11.

19）宮本文穂, 平田勝己, 鄭 勝仁 : プレストレスト合 成桁の弾塑性挙動解析と性能評価に関する研究, 土 木学会論文集,No.513/ I -31, pp.65-76, 1995.4.

20) 鄭 勝仁, 中村秀明, 宮本文穂 : 外ケーブルプレス トレス補強設計のシステム化に関する研究, 土木学 会論文集,No.623/VI-43, pp.203-218, 1999.6 .

21) 安居院猛, 長尾智晴 : ジェネティックアルゴリズム, 昭晃堂, 1993.9.

\title{
APPLICATION OF GENETIC ALGORITHM- BASED RELAY SEARCH METHOD FOR STRUCTURE DESIGN-STRENGTHENING PROBLEM
}

\author{
Katsuji TEI, Hideaki NAKAMURA, Ayaho MIYAMOTO and Mitsuru FUJIWARA
}

\begin{abstract}
This paper describes Genetic Algorithm with Relay Search Method, RS-GA, which is developed in this study to search the multiple design variables in the design space. RS-GA which is based on simple-GA, consists of some functions to search many variables from some wide variable space. It repeats simple-GA, that is the convergence process of simple-GA, which makes many time reiteration itself. From the results of the case studies, it was found that RS-GA can search all peak-variables from the 2-D functions including 5 peaks subject to a variable, whereas simple-GA can search only one or two peaks and fails to search more peak. Finally, RS-GA applied for designstrengthening problems in composite plate girder bridges using the external prestressing technique is also verified.
\end{abstract}

